J. Akademika Kim. 5(2): 55-60, May 2016

ISSN 2302-6030 (p), 2477-5185 (e)

\title{
ADSORPSI LOGAM TIMBAL (Pb) DARI LARUTANNYA DENGAN MENGGUNAKAN ADSORBEN DARI TONGKOL JAGUNG
}

\author{
Adsorption of Lead (Pb) from Its Solution by using Corncob as an Adsorbent
}

*Dwi Arista Ningsih, Irwan Said, dan Purnama Ningsih

Pendidikan Kimia/FKIP - Universitas Tadulako, Palu - Indonesia 94118

Received 01 March 2016, Revised 03 April 2016, Accepted 02 May2016

\begin{abstract}
Heavy metals will cause environmental problems. One of the efforts that can minimize level of heavy metal from their solutions is to reduce heavy metals content, so that safely discarded at sealriver. One such way to reduce level of heavy metals is by adsorption. Some agricultural waste are potential as an adsorbent, namely a corncob. Therefore, the aim of this study is to determine the optimum weight of adsorben from corncob to absorb Pb(II) from its solution. In this study, the corncob is used as an adsorbent to adsorb $\mathrm{Pb}$ (II) by using three methods, namely powder, charcoal and activated charcoal with a solution of $\mathrm{HCl}$. The parameters tested are amount of adsorbent or weight of the powder, charcoal and activated charcoal by the weight variation of $20,40,60,80$ and $120 \mathrm{mg}$ to determine the optimum conditions in absorbing $\mathrm{Pb}(\mathrm{II})$. The optimum conditions are obtained for the powder is $80 \mathrm{mg}$ with the absorption of $96.92 \%$, the charcoal is $80 \mathrm{mg}$ with absorption of $97.29 \%$, and the activated charcoal is $40 \mathrm{mg}$ with the absorption of $94.70 \%$.
\end{abstract}

Keywords: Corncob, activated charcoal, lead, adsorption

\section{Pendahuluan}

Indonesia sebagai negara agraria banyak memproduksi hasil pertanian. Kegiatan ini akan menghasilkan banyak limbah yang belum dimanfaatkan secara maksimal. Bahan limbah yang jumlahnya besar adalah limbah lingo selulosik seperti tongkol jagung, sekam, jerami dan sebagainya. Namun kegiatan pascapanen dan pengolahan hasil pertanian, termasuk pemanfaatan produk samping dan sisa pengolahannya masih kurang. Sisa pengolahan industri pertanian pada jagung akan menghasilkan limbah yang jumlahnya akan terus bertambah seiring dengan peningkatan kegiatan pascapanen yang akan mengakibatkan pencemaran lingkungan. Seiring dengan semakin meningkatnya produksi jagung, maka tidak dapat dipungkiri bahwa keberadaan limbah hasil pengolahan jagung juga akan semakin meningkat. Limbah yang dihasilkan diantaranya adalah tongkol jagung. Tongkol jagung yaitu bagian dari buah jagung yang sudah tidak mengandung biji. Sebagian besar masyarakat hanya menganggap tongkol jagung

*Correspondence:

Dwi Arista Ningsih

Program Studi Pendidikan Kimia, Fakultas Keguruan dan

Ilmu Pendidikan, Universitas Tadulako

email: dwiarista93@yahoo.com

Published by Universitas Tadulako 2016 sebagai sampah atau sebagai pakan ternak yang tidak memiliki nilai tambah. Tongkol jagung mengandung $41 \%$ selulosa, $36 \%$ hemiselulosa, $16 \%$ lignin dan $8 \%$ zat-zat lain (Subekti, 2006). Tongkol jagung dapat digunakan sebagai adsorben logam Pb (Alfiany, dkk., 2013).

Keberadaan logam berat yang tinggi disuatau perairan dapat menurunkan mutu air serta membahayakan lingkungan dan organisme perairan. Beberapa metode yang dapat digunakan untuk menurunkan konsentrasi ion logam dalam limbah cair diantaranya adalah pengendapan, penukar ion dengan menggunakan resin, filtrasi dan adsorpsi. Adsorpsi merupakan metode yang paling umum dipakai karena memiliki konsep yang lebih sederhana dan juga ekonomis. Proses adsorpsi yang paling berperan adalah adsorben. Dewasa ini telah dikembangkan metode adsorpsi dengan menggunakan biomassa tumbuhan yang dikenal dengan fitofiltrasi. Dasar pemikiran dari fitofiltrasi adalah dengan mengunakan biomassa tumbuhan yang telah mati sebagai pengikat ion logam (Tangio, 2013). Selain itu telah dikembangkan pula beberapa jenis adsorben untuk mengadsorpsi logam berat, salah satunya adalah dengan memanfaatkan selulosa. Selulosa memiliki 
gugus fungsi yang dapat meIakukan pengikatan dengan ion Iogam. Gugus fungsi tersebut adalah gugus karboksil dan hidroksil (Ibbet, dkk., 2006).

Arang aktif telah banyak dimanfaatkan sebagai adsorben logam berat, diantaranya oleh Apriani, dkk., (2013) yang memanfaatkan arang aktif dari kulit durian dengan aktivator $\mathrm{KOH} 25 \%$ sebagai adsorben logam $\mathrm{Fe}$ pada air gambut dengan kapasitas adsorpsi mencapai $85.38 \%$. Adsorpsi menggunakan adsorben adalah proses yang paling populer dan efektif untuk menghilangkan logam berat dari limbah cair. Proses adsorpsi menawarkan fleksibilitas dalam desain dan operasi pada banyak kasus. Perlakuan yang dilakukan cocok untuk menghilangkan warna dan bau serta adsorbennya dapat digunakan kembali. Proses adsorpsi kadang-kadang bersifat reversible sehingga regenerasi adsorben dimungkinkan (O'Connell, dkk., 2008).

Beberapa biomassa yang dijadikan sebagai arang aktif misalnya penelitian dari Adinata (2013) mengenai pemanfaatan limbah kulit pisang sebagai karbon. Kemudian penelitian Sukarta (2014) mengenai pemanfaatan arang aktif tempurung kelapa sawit dan tongkol jagung sebagai adsorben logam berat pada limbah batik. Berdasarkan uraian di atas sehingga muncul pemikiran untuk memanfaatkan limbah hasil jagung untuk diaplikasikan menjadi adsorben pada penyerapan logam $\mathrm{Pb}$ dari larutannya. Tujuan dari penelitian ini yaitu untuk menentukan berat optimum adsorben dari tongkol jagung dalam mengadsorpsi larutan $\mathrm{Pb}$.

\section{Metode}

\section{Alat dan Bahan}

Alat yang digunakan pada penelitian ini yaitu blender, ultra centrifugal mill, oven, tanur, ayakan 70 mesh, magnetic stirer, neraca ohaus, $\mathrm{pH}$ meter, corong, shaker, spatula, labu ukur $500 \mathrm{~mL}$, gelas kimia $100 \mathrm{~mL}$, erlenmeyer 250 dan $50 \mathrm{~mL}$, gelas ukur 500, 25 dan $5 \mathrm{~mL}$, batang pengaduk, aluminium foil, $\mathrm{pH}$ meter dan spektrofotometer direct (Lovibond).

Bahan yang digunakan pada penelitian ini yaitu serbuk dan arang tongkol jagung, larutan $\mathrm{HCl} 0,1 \mathrm{~N}, \mathrm{~Pb}\left(\mathrm{NO}_{3}\right)_{2}$ (Aldrich), aquades dan kertas saring waltman.

\section{Cara Kerja}

Bahan baku serbuk pada penelitian ini yaitu limbah tongkol jagung. Proses pembuatan serbuk tongkol jagung, langkah pertama yang dilakukan yaitu mencuci dan menjemur potongan tongkol jagung di bawah sinar matahari selama 7-8 hari. Kemudian menghaluskan potongan tongkol jagung menggunakan blender, lalu untuk memperoleh hasil yang lebih halus lagi pada penelitian ini menggunakan ultra centrifugal mill. Setelah kering, tongkol jagung tersebut di keringkan kembali menggunakan oven pada suhu $60^{\circ} \mathrm{C}$ selama 24 jam. Langkah selanjutnya yaitu menyaring serbuk tongkol jagung tersebut menggunakan ayakan 70 mesh. Ukuran 70 mesh dipilih berdasarkan hasil penelitian Sunarya dalam Sulistyawati (2008), karena memberikan kapasitas adsorpsi yang tinggi. Ukuran partikel adsorben adalah salah satu faktor yang memengaruhi adsorpsi. Pada metode tumpak, ukuran butir adsorben yang semakin kecil akan meningkatkan luas permukaan (Demirbas, dkk., 2004).

Pembuatan arang tongkol jagung yaitu dengan memasukkan serbuk tongkol jagung yang diperoleh sebelumnya ke dalam tanur pada suhu $300^{\circ} \mathrm{C}$ selama 1,5 jam sampai menjadi arang tongkol jagung. Setelah itu menghaluskan arang dengan ayakan 70 mesh.

Tahap selanjutnya dari proses pembuatan arang kimia dengan menggunakan larutan $\mathrm{HCl} 0,1 \quad \mathrm{~N} . \quad 25$ gram arang aktif yang terbentuk kemudian mengaktifkannya dengan menambahkan larutan $\mathrm{HCl}$ 0,1 N sebanyak $250 \mathrm{~mL}$. Kemudian mengaduknya dengan menggunakan magnetic stirer selama 10 menit lalu mendiamkannya selama $24 \mathrm{jam}$. Setelah itu memisahkan arang aktif yang sudah diaktivasi dengan larutan $\mathrm{HCl}$ 0,1 N menggunakan kertas saring whaltman, kemudian mencuci arang aktif sampai $\mathrm{pH}$ arang aktif tersebut netral dengan menggunakan aquades. Langkah selanjutnya yaitu mengeringkan arang aktif yang berada diwadah pada suhu $105^{\circ} \mathrm{C}$ menggunakan oven selama 3 jam untuk melakukan proses pengeringan dan penghilangan kadar air yang masih terdapat di dalam arang.

\section{Hasil dan Pembahasan}

Penelitian ini dilakukan untuk mengetahui berat optimum adsorben dari tongkol jagung dalam mengadsorpsi larutan $\mathrm{Pb}$. Metode yang digunakan dalam penelitian ini adalah melakukan adsorpsi larutan $\mathrm{Pb}$ dari adsorben tongkol jagung berupa serbuk, arang dan arang aktif.

\section{Variasi Berat Serbuk Tongkol Jagung Terhadap Adsorpsi Logam Timbal \\ Pengaruh jumlah adsorben merupakan parameter penting karena dapat menentukan}


kapasitas adsorben selama penambahan konsentrasi adsorbat. Variasi berat serbuk tongkol jagung yaitu 20, 40, 60, 80 dan 120 $\mathrm{mg}$, larutan yang digunakan adalah larutan $\mathrm{Pb}$ (II) dengan kosentrasi 58,86 ppm. Data hasil pengukuran konsentrasi $\mathrm{Pb}$ pada variasi berat serbuk terhadap adsorpsi logam timbal diperlihatkan pada Tabel 1 berikut.

Tabel 1. Hasil Pengukuran Konsentrasi $\mathrm{Pb}$ yang Teradsorpsi pada Variasi berat Serbuk Tongkol Jagung.

\begin{tabular}{ccccc}
\hline $\begin{array}{c}\text { Berat } \\
(\mathrm{mg})\end{array}$ & $\begin{array}{c}\mathrm{C}_{\mathrm{i}} \\
(\mathrm{mg} / \mathrm{L})\end{array}$ & $\begin{array}{c}\mathrm{C}_{\mathrm{eq}} \\
(\mathrm{mg} / \mathrm{L})\end{array}$ & $\begin{array}{c}\mathrm{C}_{\mathrm{b}} \\
(\mathrm{mg} / \mathrm{L})\end{array}$ & $\begin{array}{c}\% \mathrm{~Pb} \\
\text { terserap }\end{array}$ \\
\hline $\mathbf{2 0}$ & 58,68 & 2,95 & 55,73 & 94,97 \\
40 & 58,68 & 5,26 & 53,42 & 91,04 \\
$\mathbf{6 0}$ & 58,68 & 2,31 & 56,37 & 96,06 \\
80 & 58,68 & 1,81 & 56,87 & 96,92 \\
120 & 58,68 & 4,39 & 54,29 & 92,55 \\
\hline Keterangan : $C_{b}=\left(C_{i}-C_{a q}\right)$ & & &
\end{tabular}

Berdasarkan data hasil tersebut dapat dilihat kurva pengukuran variasi berat serbuk tongkol jagung terhadap logam $\mathrm{Pb}$ dapat pada Gambar 1.

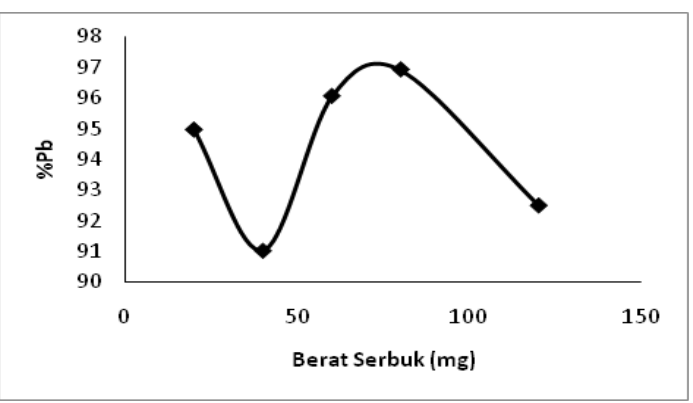

Gambar 1. Kurva Hubungan antara Berat Serbuk Tongkol Jagung terhadap $\% \mathrm{~Pb}$ terserap

Dari data berat adsorben semakin meningkat pada berat 20, 60 dan $80 \mathrm{mg}$ sehingga menyebabkan naiknya persentase logam timbal yang terserap. Hal tersebut menunjukkan bahwa berat adsorben berpengaruh terhadap proses adsorpsi karena semakin bertambahnya berat adsorben, maka nilai $\% \mathrm{~Pb}$ teradsorpsi terhadap ion juga semakin meningkat dan mencapai kesetimbangan. Akan tetapi pada berat adsorben $40 \mathrm{mg}$ mengalami penurunan. Kecilnya daya serap timbal ini disebabkan waktu kontak antara adsorbat dan adsorben yang melebihi waktu optimum dapat menyebabkan desorpsi. Atkins 1990 dalam Amir, dkk., (2013) mendefinisikan desorpsi sebagai pelepasan adsorbat dari permukaan adsorben. Fenomena ini terjadi akibat jenuhnya permukaan adsorben, sehingga melekul adsorbat yang telah terserap kembali kedalam larutan.

Sukarta (2014) menyatakan jumlah zat yang diadsorpsi pada permukaan adsorben merupakan proses berkesetimbangan, sebab laju peristiwa adsorpsi disertai dengan terjadinya desorpsi. Pada awal reaksi, peristiwa adsorpsi lebih dominan dibandingkan dengan peristiwa desorpsi, sehingga adsorpsi berlangsung cepat. Pada waktu tertentu peristiwa adsorpsi cendung berlangsung lambat, dan sebaliknya laju desorpsi cendrung meningkat. Waktu ketika laju adsorpsi adalah sama dengan laju desorpsi sering disebut sebagai keadaan berkesetimbangan. Pada keadaan berkesetimbangan tidak teramati perubahan secara makroskopis. Waktu tercapainya keadaan setimbang pada proses adsorpsi berbeda-beda, $\mathrm{Hal}$ ini dipengaruhi oleh jenis interaksi yang terjadi antara adsorben dengan adsorbat.

Kemudian pada berat $120 \mathrm{mg}$ penyerapannya pun menurun. Hal tersebut disebabkan oleh adsorben yang sudah jenuh. Anjani (2014) menyatakan bahwa pada saat tersebut proses adsorpsi dinyatakan berhenti karena berdasarkan nilai $\% \mathrm{~Pb}$ teradsorpsi telah mendekati kesetimbangan karena jumlah molekul adsorbat yang berikatan dengan adsorben semakin sedikit. Hal tersebut dikarenakan jumlah adsorben mempengaruhi proses adsorpsi dimana semakin bertambahnya berat menyebabkan adsorben telah mencapai titik jenuh jika permukaannya telah terisi oleh adsorbat.

Kondisi optimum ditentukan berdasarkan kapasitas adsorpsi (Q) tertinggi dari masingmasing parameter. Barros menyatakan bahwa peningkatan bobot adsorben akan menyediakan tapak aktif yang lebih besar, sehingga meningkatkan persentase penyerapan. Menurunnya kapasitas adsorpsi setelah mencapai nilai maksimum dimungkinkan karena proses desorpsi atau pelepasan adsorbat kembali selama pengocokan. Desorpsi terjadi akibat permukaan adsorben yang telah jenuh. Pada keadaan jenuh, laju adsorpsi menjadi berkurang (Barros, 2003).

Pada penelitian ini adsorpsi dari serbuk tongkol jagung lebih besar dibandingkan dengan adsorpsi dari arang dan arang aktif. Selain dikarenakan adanya desorpsi pada arang dan arang aktif, Irawadi dalam Subekti (2006) 
menyatakan tongkol jagung mengandung selulosa 41\%, hemiselulosa 36\%, lignin 16\% dan zat-zat lainnya $8 \%$.

Mohadi, dkk., (2013) menyatakan pemeriksaan dengan sinar $\mathrm{X}$ menunjukkan bahwa selulosa terdiri dari bagian amorf dan kristalin. Bagian kristalin adalah bagian serat dimana susunan molekul seratnya sejajar dengan sumbu serat, sedangkan bagian amorf adalah bagian serat dimana susunan molekulnya sembarang. Beberapa sifat serat terutama bergantung pada bagian amorf, misalnya penyerapan uap air, pencelupan dan pembengkakan. Hal ini disebabkan kristalin pada daerah amorf susunan gugus $\mathrm{OH}$ tidak teratur sehingga dapat mengadakan ikatan hidrogen dengan molekul air, sedangkan pada daerah kristalin sebagian besar gugus $\mathrm{OH}$ tersusun teratur dan rapat. Ion logam berat akan terikat pada gugus hidroksil atau gugus yang memiliki pasangan elektron sunyi dari suatu bahan organik, dengan demikian gugusgugus yang berperan dalam adsorpsi adalah gugus hidroksil $(-\mathrm{OH})$.

Dilihat dari strukturnya, selulosa, lignin dan hemiselulosa mempunyai potensi yang cukup besar untuk dijadikan sebagai penyerap karena gugus $\mathrm{OH}$ yang terikat dapat berinteraksi dengan komponen adsorbat (Sukarta, 2014).

\section{Variasi Berat Arang Tongkol Jagung Terhadap Adsorpsi Logam Timbal}

Hasil pengukuran konsentrasi $\mathrm{Pb}$ pada variasi berat arang terhadap adsorpsi logam timbal diperlihatkan pada Tabel 2 berikut.

Tabel 2. Hasil Pengukuran Konsentrasi $\mathrm{Pb}$ yang Teradsorpsi pada Variasi berat Arang Tongkol

\begin{tabular}{ccccc}
\multicolumn{5}{c}{ Jagung. } \\
\hline $\begin{array}{c}\text { Berat } \\
(\mathrm{mg})\end{array}$ & $\begin{array}{c}\mathrm{C}_{\mathrm{i}} \\
(\mathrm{mg} / \mathrm{L})\end{array}$ & $\begin{array}{c}\mathrm{C}_{\mathrm{eq}} \\
(\mathrm{mg} / \mathrm{L})\end{array}$ & $\begin{array}{c}\mathrm{C}_{\mathrm{b}} \\
(\mathrm{mg} / \mathrm{L})\end{array}$ & $\begin{array}{c}\% \mathrm{~Pb} \\
\text { terserap }\end{array}$ \\
\hline $\mathbf{2 0}$ & 58,68 & 6,38 & 52,3 & 89,13 \\
$\mathbf{4 0}$ & 58,68 & 4,12 & 54,56 & 92,98 \\
$\mathbf{6 0}$ & 58,68 & 3,36 & 55,32 & 94,27 \\
$\mathbf{8 0}$ & 58,68 & 1,59 & 57,09 & 97,29 \\
120 & 58,68 & 6,85 & 51,83 & 88,32 \\
\multicolumn{5}{c}{ Keterangan : $C_{b}=\left(C_{i}-C_{e q}\right)$} \\
\end{tabular}

Berdasarkan data hasil tersebut dapat dilihat kurva pengukuran variasi berat serbuk tongkol jagung terhadap logam $\mathrm{Pb}$ dapat pada Gambar 2.

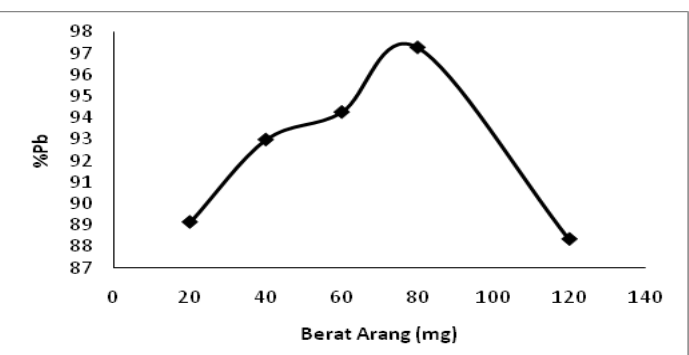

Gambar 2. Kurva Hubungan antara Berat Arang terhadap $\% \mathrm{~Pb}$ terserap

Dari data yang disajikan, dimana dengan meningkatnya berat adsorben dari 20-80 mg logam timbal yang terserap juga akan meningkat, namun pada berat adsorben 120 mg serapannya relatif menurun.

Terjadinya peningkatan adsorpsi logam timbal pada berat arang aktif 20-80 mg menunjukkan bahwa berat adsorben berpengaruh terhadap proses adsorpsi karena semakin bertambahnya berat adsorben, maka nilai $\% \mathrm{~Pb}$ teradsorpsi terhadap ion juga semakin meningkat dan mencapai kesetimbangan karena kerapatan sel arang dalam larutan sehingga menghasilkan interaksi yang cukup efektif antara pusat aktif dinding sel arang aktif dengan logam timbal, semakin banyak zat penyerap maka semakin banyak pusat aktif arang yang teraktivasi yang bereaksi (Radyawati, 2011).

Selanjutnya adsorpsi logam timbal menurun pada berat arang aktif $120 \mathrm{mg}$. Hal ini disebabkan karena ion-ion timbal yang terdapat di dalam larutan telah teradsorpsi sepenuhnya oleh arang aktif, dengan kata lain ion timbal pada larutan telah habis teradsorpsi oleh arang. Proses adsorpsi dan desorpsi pada adsorben dapat dilihat pada Gambar 3.

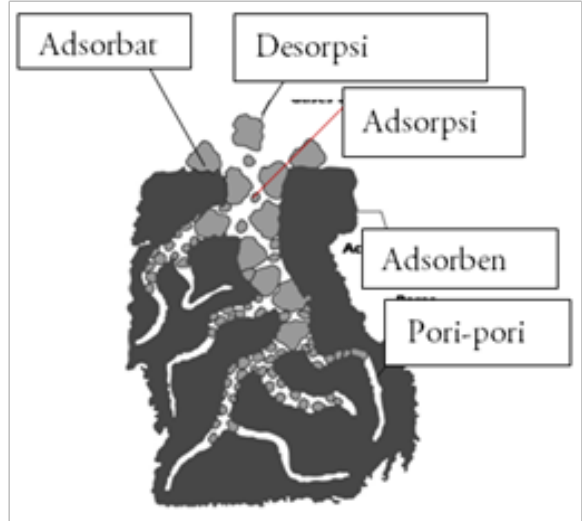

Gambar 3. Proses adsorpsi dan desorpsi ke dalam pori-pori adsorben (Lestari, 2010) 
Variasi Berat Arang Aktif Tongkol Jagung Terhadap Adsorpsi Logam Timbal

Data hasil pengukuran konsentrasi $\mathrm{Pb}$ pada variasi berat arang aktif terhadap adsorpsi logam timbal diperlihatkan pada Tabel 3 berikut.

Tabel 3. Hasil Pengukuran Konsentrasi $\mathrm{Pb}$ yang Teradsorpsi pada Variasi berat Arang Aktif Tongkol Jagung.

\begin{tabular}{ccccc}
\hline $\begin{array}{c}\text { Berat } \\
(\mathrm{mg})\end{array}$ & $\begin{array}{c}\mathrm{C}_{\mathrm{i}} \\
(\mathrm{mg} / \mathrm{L})\end{array}$ & $\begin{array}{c}\mathrm{C}_{\mathrm{eq}} \\
(\mathrm{mg} / \mathrm{L})\end{array}$ & $\begin{array}{c}\mathrm{C}_{\mathrm{b}} \\
(\mathrm{mg} / \mathrm{L})\end{array}$ & $\begin{array}{c}\% \mathrm{~Pb} \\
\text { terserap }\end{array}$ \\
\hline 20 & 58,68 & 5,29 & 53,39 & 90,98 \\
40 & 58,68 & 3,11 & 55,57 & 94,70 \\
60 & 58,68 & 3,21 & 55,47 & 94,53 \\
80 & 58,68 & 5,25 & 53,43 & 91,05 \\
120 & 58,68 & 6,14 & 52,54 & 89,53 \\
\hline \multicolumn{4}{l}{ Keterangan : $C_{b}\left(C_{i}-C_{e q}\right)$} \\
\end{tabular}

Berdasarkan data hasil tersebut dapat dilihat kurva pengukuran variasi berat serbuk tongkol jagung terhadap logam $\mathrm{Pb}$ dapat pada Gambar 4.

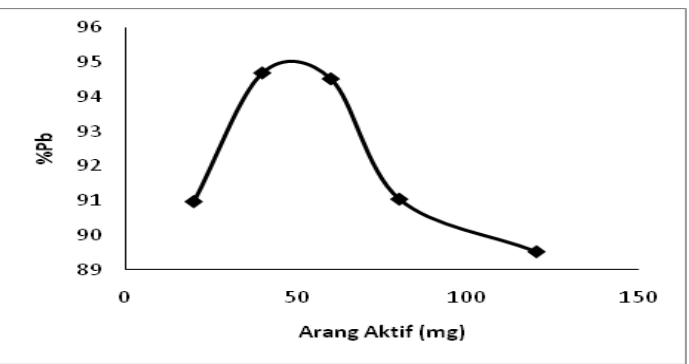

Gambar 4. Kurva Hubungan antara Berat Arang Aktif terhadap \% $\mathrm{Pb}$ Terserap

Data yang disajikan pada Gambar 4 dengan meningkatnya berat adsorben dari $20-40 \mathrm{mg}$ sehingga menyebabkan naiknya persentase logam timbal yang terserap, namun pada berat adsorben $60-120 \mathrm{mg}$ serapannya relatif menurun.

Peningkatan adsorpsi tersebut disebabkan karena bertambahnya jumlah arang aktif yang berinteraksi dengan logam timbal. Terjadinya peningkatan adsorpsi logam timbal pada berat arang aktif 20-40 mg, karena kerapatan sel arang dalam larutan sehingga menghasilkan interaksi yang cukup efektif antara pusat aktif dinding sel arang aktif dengan logam timbal, semakin banyak zat penyerap maka semakin banyak pusat aktif arang yang teraktivasi yang bereaksi.

Selanjutnya adsorpsi logam timbal menurun pada berat arang aktif $60-120 \mathrm{mg}$. Hal ini menunjukkan bahwa berat adsorben berpengaruh terhadap proses adsorpsi karena semakin bertambahnya berat adsorben, maka nilai $\% \mathrm{~Pb}$ teradsorpsi terhadap ion juga semakin meningkat dan mencapai titik jenuh.

Berdasarkan penelitian dari Valentina, dkk., (2013) yang mengatakan bahwa arang aktif memiliki pori-pori yang lebih besar dibandingkan dengan arang non aktivasi, sehingga menyebabkan proses penyerapannya lebih besar. Terlihat pada hasil penelitian ini mengenai variasi berat arang tongkol jagung, berat optimum arang diperoleh pada berat 80 mg sedangkan pada variasi berat arang aktif tongkol jagung, berat optimum berada pada $40 \mathrm{mg}$ arang aktif tongkol jagung. Dengan kata lain arang aktif lebih cepat jenuh dengan ion-ion logam yang akan diserap dibandingkan arang biasa.

\section{Kesimpulan}

Berat optimum yang diperlukan serbuk tongkol jagung untuk menyerap logam timbal sebesar 58,68 ppm adalah $80 \mathrm{mg}$ dan persentase logam timbal yang terserap yaitu $96,92 \%$. Berat optimum yang diperlukan arang tongkol jagung untuk menyerap logam timbal sebesar 58,68 ppm adalah $80 \mathrm{mg}$ dan persentase logam timbal yang terserap yaitu 97,29\%. Berat optimum yang diperlukan arang aktif tongkol jagung untuk menyerap logam timbal sebesar $58,68 \mathrm{ppm}$ adalah $40 \mathrm{mg}$ dan persentase logam timbal yang terserap yaitu $94,70 \%$.

\section{Ucapan Terima Kasih}

Penulis mengucapkan terima kasih kepada kepala laboran laboratorium Agroteknologi FAPERTA dan semua pihak yang telah membantu dalam pelaksanaan penelitian ini.

\section{Referensi}

Adinata. (2013). Pemanfaatan limbah kulit pisang sebagai karbon aktif. (Skripsi), Universitas Pembangunan Nasional Veteran Jawa Timur.

Alfiany, H., Bahri, S. \& Nurakhirawati. (2013). Kajian penggunaan arang aktif tongkol jagung sebagai adsorben logam $\mathrm{Pb}$ dengan beberapa activator asam. Journal Natural Science, 2(3), 75-86. 
Anjani, R. P. (2014). Penentuan massa dan waktu kontak optimum adsorpsi karbon granular sebagai adsorben logam berat $\mathrm{Pb}$ (II) dengan pesaing ion $\mathrm{Na}+$. Journal of Chemistry, 3(3), 159-163.

Apriani, R., Faryuni, I. D. \& Wahyuni, D. (2013). Pengaruh konsentrasi aktivator kalium hidroksida $(\mathrm{KOH})$ terhadap kualitas karbon aktif kulit durian sebagai adsorben logam Fe pada air gambut. Prisma Fisika, 2(1), 82-86.

Barros, J. (2003). Biosorption of cadmium using the fungus aspergillus niger. Brazilian Journal Of Chemical Engineering, 20, 1-17.

Demirbas, E., Kobya, M., Senturk, E. \& Ozkan, T. (2004). Adsorption kinetics for the adsorbent of chromium(VI) from aqueous solutions on the activated carbons prepared from agricultural wastes. Water SA, 30, 533-540.

Ibbet, R. N., Kaenthong, S., Philips, D. A. S. \& Wilding, M. A. (2006). Charaterisatim of porosity of regenerated cellulosil fibres using classical dye adsorbtion techniques. Lenzinger Berichte, 88, 77-86.

Lestari, S. (2010). Pengaruh berat dan waktu kontak untuk adsorpsi timbal(II) oleh adsorben kulit batang jambu biji (psidium guajava L.). Jurnal Kimia Mulawarman, 8(1), 6-9.

Mohadi, R., Saputra, A., Hidayati, N. \& Lesbani, A. (2013). Studi interaksi ion logam Mn2+ dengan selulosa dari serbuk kayu. Jurnal Kimia, 8(1), 1-8.

O'Connell, D.W, Brikinshaw, C. \& O’Dwyer, T. F. (2008). Heavy metal adsorbents prepared from the modification of cellulose. Journal Bioresource Technology, 99(6711), 6709-6724.

Radyawati. (2011). Pembuatan biocharcoal dari kulit pisang kepok untuk penyerapan logam timbal $(\mathrm{Pb})$ dan logam seng $(\mathrm{Zn})$. Palu: UNTAD - Press.

Subekti, H. (2006). Produksi etanol dari hidrolisa fraksi selulosa tongkol jagung oleh saceharomyces cerevisiae. (Skripsi), Institute Pertanian Bogor.

Sukarta, F. (2014). Pemanfaatan arang aktif tempurung kelapa sawit dan tongkol jagung sebagai adsorben logam berat pada limbah batik. (Skripsi), Institute Pertanian Bogor.

Sulistyawati. (2008). Modifikasi tongkol jagung sebagai adsorben logam berat $\mathrm{Pb}(\mathrm{II})$. (Skripsi), Institut Pertanian Bogor.

Tangio. (2013). Adsorpsi logam timbal (Pb) menggunakan biomassa eceng gondok. Jurnal Entropi, 8(1), 500-506.

Valentina, Miswadi \& Latifah. (2013). Pemanfaatan arang eceng gondok dalam menurunkan kekeruhan, COD, BOD pada air sumur. Indonesian Journal of Chemical Science, 2(2), 84-89. 